- Ambrosino, G., and Pindrus, P., Rev, Métall., 50, 136 (1953).

${ }^{10}$ Emoto, Y., Sci. Papers Jap. Antiques, 13, 37 (1956).

${ }^{11}$ Sayre, E. V., and Dodson, R. W., Amer. J. Archeol., 61, 35 (1957).

12 Sayre, T. V., Murrenhoff, A., and Weick, C. F., The Nondestructive Analysis of Ancient Potsherds through Neutron Activation, BrookhavenNational Lab. Report BNL $508(T-122)$ (1958).

${ }^{13}$ Gordus, A. A., Energetic Recoil Atom Reaction Mechanisms (Progress report for A.E.C. Contract $A T(11-1)-912)$, Univ. Michigan, Office Res. Admin., $49(1965)$.

${ }^{14}$ Emeleus, V. M., Archaeometry, 1, 6 (1958).

15 Emeleus, V. M., thesis, Univ, Oxford (1959).

${ }^{16}$ Emeleus, V. M., Archaeometry, 3, 16 (1960).

17 Emeleus, V. M., and Simpson, G., Nature, 185, 196 (1960).

${ }_{18}$ Simpson, G., Archaeometry, 3, 20 (1960).

${ }^{18}$ Kraay, C. M., Archaeometry, 1, 1 (1958).

${ }^{20}$ Kraay, C. M., Archaeometry, 2, 1 (1959).

${ }^{21}$ Aitken, M. J., Emeleus, V. M., Hall, E. T., and Kraay, C. M., Radioisotopes in Physical Sciences (Copenhagen conference), RICC/37 (International Atomic Energy Authority, Vienna, 1960).

${ }^{22}$ Kraay, C. M., and Emeleus, V. M., The Composition of Greek Silver Coins, Analysis by Neutron Activation (visitors of the Ashmolean Museum, Oxford, 1962)

${ }^{23}$ Ravetz, A., Archaeometry, 6, 46 (1963).

24 Hall, E. T., and Roberts, G., Archueometry, 5, 28 (1962).

${ }^{25}$ Das, H. A., and Zonderhuis, J., A rchaeometry, 7\%, 90 (1964).

${ }^{26}$ Bluyssen, H., and Smith, PH. B., Archaeometry, 5, 113 (1962).
ADDITIONAL REFERENOES

Bennyhoff, J. A., and Heizer, R. F., "Neutron Activation Analysis of some Cuicuilco and Teotihuacán Pottery: Archaeological Interpretation of Results", Amer. Antiq., 30, 348 (1965).

Boston Museum of Fine Arts, Applications of Science in Examination of Works of Art (Proc. Seminar Res
Arts, Boston) (Boston, 1958).

Hodges, H., Artifacts: an Introduction to Early Materials and Technology (London, 1964)

Johnson, R. A., and Stross, F. H., "Laboratory-scale Instrumental Neutron Activation for Archaeological Analysis", Amer. Antiq., 30, 345 (1965).

Sayre, E. V., "Authentication of Ancient Artifacts by Nuclear Means", Trans. Ámer. Nucl. Soc., 5, 283 (1962).

Sayre, E. V., "Methods and Applications of Activation Analysis", Ann. Rev: Nucl. Sci., 13, 145 (1963).

Seaborg, G. T., "Science and the Humanities", Science, 144, 1199 (1964).

Shepard, A. O., Ceramics for the Archaeologist, Carnegie Institute of Washington, Publication 609 (1956)

Smith, R. W., "Technological Research on Ancient Glass", Archacology, 11,

Sutherland, C. H. V., and Harold, M., R., “The Silver Content of Diocletian's Farly Post-reform Copper Coins", Árchaeometry, 4, 56 (1961).

Thompson, M., "Gold and Copper Traces in Late Athenian Silver", Archaeometry, 3, $10(1960)$.

Zuber, K., Neutron Activation Analysis of Roman Copper Coins from 250-500 A.D., Part 1, Rep. of Cekmece Nucl. Res. Cent., Istanbul, Turkey, T.A.F.C. ONAEM, 21 (1965).

\title{
OBITUARIES
}

\section{Prof. H. J. Bhabha}

Prof. Hom Jehangir BhabHa, chairman of the Indian Atomic Energy Commission, was killed with 116 others in an air-crash on Mont Blanc on January 24. He was on his way to Vienna to attend a meeting of the Scientific Advisory Committee of the International Atomic Energy Agency. He was a member of the Advisory Committee, and also of the Agency. Bhabha was a leader of science of the highest distinction, and his untimely death under poignant circumstances, at the height of his powers and influence, is a stunning blow to Indian science. It has left a void which will be difficult to fill. He was a theoretical physicist of world fame and one of the most gifted of scientific administrators to be found anywhere. The phenomenal progress made by India in atomic energy research and development will ever remain a lasting monument to Bhabha's vision, drive and dedication. He was a pioneer in several ways; and his great example will continue to be a source of inspiration for many years to come.

Homi Bhabha was born in Bombay on October 30 , 1909 , into a wealthy Parsee family related to the House of Tatas--he was a nephew of Lady Dorab Tata. He received his early education at the Cathedral and John Connon High School, Elphinstone College, and the Institute of Science, Bombay. After a brilliant academic record in India he joined Gonville and Caius College at Cambridge. He took the Mechanical Sciences Tripos in 1930. From 1932 until 1934 he held the Rouse Ball travelling studentship in mathematics, and worked with W. Pauli in Zurich and E. Fermi in Rome. He was awarded an Isaac Newton studentship in 1934, and a senior studentship of the Exhibition of 1851 in 1936 . In 1940 he accepted a readership in theoretical physics, specially created for him, at the Indian Institute of Science, Bangalore. $\mathrm{He}$ was appointed professor in 1942. In 1945 he moved to Bombay to assume the directorship of the Tata Institute of Funda. mental Research. The Institute, established at Bhabha's initiative, was made possible by a donation from the Sir Dorab Tata Trust. The Institute now has an academic staff of more than 200 and is almost entirely supported by the Atomic Energy Commission. It is interesting to recall that in 1944 Bhabha, in making his proposal to the Tata Trust, stated that his aim was "to build in the course of time a school of physics comparable to the best anywhere", and he continued, "when nuclear energy has been successfully applied for power production in say a couple of decades from now, India will not have to look abroad for its experts but will find them ready at hand".
That all this has come about is a tribute as much to his vision as to his determination and single-mindedness in the pursuit of the goal that he had set for himself.

The Atomic Energy Act of India was passed in 1948. Under the Act the Atomic Energy Commission was sot up with Bhabha as its chairman; he was also appointed secretary to the Department of Atomic Energy directly under the Prime Minister, in addition to the directorship of the Tata Institute of Fundamental Research and the Atomic Energy Research Establishment at Trombay. $\mathrm{He}$ enjoyed in full measure from the very beginning the support and confidence of the late Prime Minister Nehru, and this enabled Bhabha to lift the atomic energy programme to a level and carry it out with a speed which otherwise would scarcely have been possible.

The name of Bhabha will always remain associated with the beautiful theory (based on radjative energy loss by electrons, and pair-creation by photons), formulated jointly with W. Heitler in 1937, which has proved of fundamental importance in the understanding of the phenomenon of electron showers in cosmic rays. The theory was put forward simultaneously by J. F. Carlson and J. R. Oppenheimer. The mathematical aspects of the theory were developed further by Bhabha and S. K. Chakrabarty in 1943.

Bhabha was one of the earliest research workers to investigate the problem of scattering of mesons by nucleons and obtained (1938) an expression analogous to the Thomson scattering for light. He was the first to predict the lengthening with increasing energy, as required by relativity, of the decay-time of cosmic ray mesons.

Bhabha was elected a Fellow of the Royal Society of London in 1941. In 1943 he was awarded the Adams Prize by the University of Cambridge for his work on cosmic rays, and in 1948 the Hopkins Prize of the Cambridge Philosophical Society. In 1963 he was elected foreign associate of the U.S. National Academy of Sciences, and an honorary life member of the New York Academy of Sciences. In 1964 he was made foreign corresponding academician of the Royal Academy of Sciences, Madrid. From 1960 until 1963 he was president of the International Union of Pure and Applied Physics. Bhabha was president of the historic International Conference on the Peaceful Uses of Atomic Energy, held under the auspices of the United Nations, at Geneva in August 1955.

Bhabha was president of the National Institute of Sciences of India in 1963, and president of the Indian Science Congress Association in 1951. He was from the very beginning a member (and later chairman) of the 
Scientific Advisory Committee to the Indian Cabinetthis Committee also acts as the National Committee for the International Council of Scientific Unions. He was a member of the Governing Body of the Indian Council of Scientific and Industrial Research, and of several committees concerned with planning and development of science. He was awarded the title of Padma Bhushan by the Indian Government in 1954. He received honorary doctorates from several universities in India and abroad, including London and Cambridge.

Bhabha's interests covered a wide range. He was fond of music, and was no mean musician and painter himself. He had a keen aesthetic sense and sophisticated tastes: the Tata Institute at Bombay is not only a great centre of vigorous research but it is also one of India's 'prestige buildings'.

He was a man of great personal charm. He was always eager to seek outstanding talent (even in fields remote from his own interests) and give it every possible encouragement. $\mathrm{He}$ had travelled extensively, and had wide international contacts. He will be sorely missed by his numerous friends in and outside India.

$\mathrm{He}$ is survived by his mother and a younger brother. D. S. KOTHARI

\section{Prof. T. J. Jenkin}

Prof. Thomas James Jenkin, who died on November 7 , 1965, was professor of agricultural botany at the University College of Wales, Aberystwyth, and director of the Welsh Plant Breeding Station from 1942 until he retired in 1950. He was an agricultural soientist of the highest repute, and his pioneer work on the breeding of improved varieties of grasses earned for him world-wide recognition.

As a young man, Jenkin could not have envisaged a scientific career, for this only became possible later by taking advantage of the few and unexpected opportunities that came his way.

Born in 1885 on a small isolated farm in North Pembrokeshire, his youthful ambition was to become a successful farmer, and for this purpose he attended, in 1907, a short course of one academic term in the University Department of Agriculture at Aberystwyth. However, in the following year he was seriously injured on the farm. This accident, which made him less fit for manual work, was probably the turning-point in his career, because it led him to further academic study. Following a continuation course of another term at Aberystwyth he was advised and encouraged to enter the Old College School at Carmarthen, where he achieved the distinction of obtaining university matriculation in one year. In 1910 he returned to Aberystwyth to read for a degree in rural science, where he graduated with first-class honours in botany in 1914 .

After a year as agricultural organizer for the Counties of Brecon and Radnor, Jenkin was appointed adviser in agricultural botany at the University College of North Wales, Bangor, where he remained until his return to Aberystwyth to occupy a similar post in 1919. This gave him the opportunity to study the botanical composition and productivity of sown pastures, when he showed that the varieties of herbage plants then available lacked persistency in the sward and were soon replaced by indigenous grasses. His work attracted the attention of Prof. (later Sir) R. G. Stapledon, and he joined the newly established Welsh Plant Breeding Station as senior research assistant in 1920. This was the beginning of a long and fruitful association between two great agricultural soientists who, although differing widely in personality and in their scientific approach and methods, made outstanding contributions to grassland improvement and productivity.

Jenkin's extensive collection of indigenous grasses, which showed considerable genetic variation, formed the basis for the deliberate breeding of improved varieties. The techniques for controlled hybridization had to be developed, but even after adequate testing of the progeny as single plants he was confronted with the problem of assessing the value of a combination of favourable genotypes when grown in a sward under highly competitive conditions. Without modern knowledge of population genetics he was extremely successful in producing a series of improved varieties which maintained their identity and performance after several generations of seed production. His variety $S 23$ of perennial ryegrass has probably contributed more to the improvement of both hill and lowland pastures in Britain than a whole series of commercial seed mixtures.

Although the greater part of his work involved the production of new varieties for use on the farm, Prof. Jenkin was able to conduct pioneer research on interspecific and inter-generic relationships of the grasses, part:cularly Lolium, Festuca and Phalaris. He was awarded the degree of D.Sc. for these investigations.

As professor and director he guided the work of the Department of Agricultural Botany and the Welsh Plant Breeding Station with distinction throughout the difficult war and immediate post-war years, and when he retired in 1950 he was made a C.B.E. He was later awarded the Gold Medal of the Royal Welsh Agricultural Society and made an Honorary Member of the Swedish Seed Association for his outstanding contribution to agriculture.

Thomas James Jenkin belonged to that unique band of pioneers who have contributed so much towards the advancement of agriculture, and future generations will acknowledge their debt to the young Pembrokeshire farmer who became an outstanding agricultural scientist.

P. T. Thомаs

\section{Prof. Ferdinand Herčík}

Prof. F. Hzrčík died on January 20 at the age of sixty. $\mathrm{He}$ was director of the Institute of Biophysies of the Czechoslovak Academy of Sciences at Brno since its inception in 1955. One of the foremost contemporary research workers of Czechoslovakia, his work was widely known throughout the world and his friendship was cherished by many of us who had the good fortune to know him well. His activities in connexion with the affairs of the United Nations Organization brought him into extensive touch with Western scientists. Being a member of the United Nations Scientific Committee on the Effects of Atomic Radiation and a governor and vicechairman of the International Atomic Energy Agency made it possible for him to travel and to meet colleagues freely at a time when contacts between Eastern and Western scientists were much more restricted than they are now. When chairman of the United Nations Scientific Committee, his tact, perseverance and unquestionable integrity made it possible for this Committee to publish a balanced and unanimous report, though there was then no test-ban treaty and the question of the hazard from fall-out was in the arena of emotion and politics. At the International Atomic Energy Agency, Prof. Herčík was tireless in his support for fundamental investigations on the biological effects of radiation, which he considered an essential part of any research programme designed to further the perceful uses of atomic energy. His unique status enabled him to ensure that investigations into the problems of health and safety were not too narrowly based and he emphasized the importance of studying chemical agents which modified the degree of biological damage produced by a given dose of radiation.

These achievements as a scientific statesman required more than technical competence, and as soon as one met him one was struck by his extremely rich personality. He was a talented and very active painter, had a passion 